\title{
Increasing small business resilience to flood risk: Co-production in the development of a prototype e-learning tool to promote small business adaptation to flood risk
}

\author{
Lindsey McEwen ${ }^{1 a}$, Amanda Wragg $^{1}$ and Tim Harries ${ }^{2}$ \\ ${ }^{1}$ Centre for Floods, Communities and Resilience, University of the West of England, Bristol,UK \\ ${ }^{2}$ Bristol Small Business Research Centre, Kingston University London,UK
}

\begin{abstract}
Flooding of communities is becoming a repeated, widespread issue within the UK, and elsewhere. Small businesses are a crucial part of the UK economy; the UK Summer 2007 flood resulted in flooding of 7,000 businesses and monetary loss to local economies. There has, however, been limited research on how small businesses learn to adapt to increase their resilience. This paper shares interdisciplinary research that has developed an innovative coproduction process to engage small businesses and the stakeholders that support them in resilience building, in partnership working to develop a prototype e-learning tool to promote longer-term adaptation to flooding amongst small businesses. The research focus here is on both the processes of the co-production and their influence on the outcome - the prototype e-learning tool. The co-production processes combined workshops, virtual engagement and co-creation of learning resources that captured business knowledge and learning on flood adaptation. Data were captured through: independent observation, audio/visual recording, transcription of discussions, and the participatory production of graphic outputs. Our approach reflects current ethics and practices of stakeholder participation within research so that other equally valid forms of knowledge are recognised and drawn on. The e-learning tool is designed as a living resource to support development of a community of learning practice among small businesses to increase resilience to increased flood risk.
\end{abstract}

\section{Introduction}

Small businesses are a crucial part of the UK economy, and whilst recent research has focused on community resilience (e.g. Twigger Ross et al., [1]), there has been less attention to understanding small business resilience, and in identifying ways to reduce their flood impacts. The flooding of communities has become a repeated, widespread issue within the UK, and elsewhere. The UK Summer 2007 floods, for example, resulted in loss of life, flooding of 48,000 houses and 7,000 businesses, community disruption, and monetary loss to local economies (Cabinet Office [2]). The winter floods of 2013/2014 and 2015/2016 have also had devastating impacts, with businesses badly affected. Small businesses ${ }^{1}$ can be integral to the economic resilience of communities (Leach [3]). They have different characteristics in comparison to large businesses. Although small businesses may be vulnerable to fluctuations in turnover and housed in vulnerable

\footnotetext{
${ }^{1}$ Micro businesses and small businesses are defined as having $<10$ and $<50$ employees respectively

a Corresponding author: Lindsey.McEwen@uwe.ac.uk
}

premises, they often have the ability to make quick decisions and be innovative in the face of adversity owing to smaller, less complex systems. This poses questions about how small businesses can be made more resilient to flooding and other stresses - both for businesses themselves and associated communities, and how to bridge the knowledge gap between flood risk policy, practice and business owners. Our research has focused on understanding business knowledge systems and networks, and how these link to longer-term adaptive learning and actionable knowledge. 


\section{Aims}

This paper shares research ${ }^{2}$ into the processes and outcomes of the co-production of a prototype e-learning tool whose aim was to promote longer-term flood risk adaptation amongst small businesses. This co-production involved owners of small businesses and representatives of organisations that support businesses in flood risk management. If it is to be effective, distributed flood risk management needs to integrate different knowledges expert, scientific and local/lay (Whatmore [4]; Lane et al. [5]; Donaldson et al., [6]) into actionable knowledge (Antonacopolou [7]). In this research, we developed a process of co-production that aimed to engage a range of partners, and to integrate the contributions of representatives of all those with an interest in the project aims and outcomes. Haughton et al. ([8], p375) argue that 'experiments in the co-production of flood risk knowledge need to be seen as part of a spectrum of ways for producing shared knowledge'. The aim of our research has been twofold: to explore the processes of coproduction in this context, and to research and develop a prototype e-learning tool for small businesses. First we outline briefly an earlier phase of our research that sets the context to our co-production processes.

\section{Earlier research: business knowledges and how businesses learn}

The first phase of work set out to comprehend how small businesses' understandings of flooding and flood risk influence their responses to this risk. We were interested in small businesses' ability to become more resilient - i.e. to accept the "new normal" by recognising the existence of an on-going flood risk (Twigger-Ross et al.[9], p32) and making adaptations to existing systems, infrastructure, resource allocations and working practices. In our analysis of the 36 interviews with businesses, we looked too at the different knowledge-systems (clusters of understandings and ways of understanding; see Whatmore, [4]) that small businesses bring to bear on the subject of resilience, and how they integrate these with the other knowledge systems that they encounter (e.g. lay knowledge systems and systems from business, science or specific institutions) for learning and understanding. We found that small businesses draw on different knowledge systems and integrate lay/local knowledge,

\footnotetext{
${ }^{2}$ A three year interdisciplinary project funded by the UK Engineering and Physical Sciences Research Council (EPSRC). See http://sesame.uk.com.
}

science and other expert knowledge shared by government agencies and business-related knowledges in their decision making.

Evidence also suggested that the top-down transfer of knowledge about risk mitigation from government agencies (environmental regulator; local government) to small businesses does not work. Our trawl of existing resources that are intended to support business resilience planning indicated that these were normally focused on short-term contingency planning, rather than long-term resilience (Table 1).

Table 1. Weblinks for "I want to make my business more resilient to flooding"

\begin{tabular}{|c|c|c|}
\hline Resource & Description & $\begin{array}{l}\text { Web } \\
\text { address }\end{array}$ \\
\hline $\begin{array}{l}\text { Climate East } \\
\text { Midlands (2012): } \\
\text { 'weathering the } \\
\text { storm - saving \& } \\
\text { making money in } \\
\text { a changing } \\
\text { climate' }\end{array}$ & $\begin{array}{l}\text { A comprehensive } \\
\text { guide to the risks } \\
\text { faced by small } \\
\text { businesses and how } \\
\text { these can be } \\
\text { reduced. Covers } \\
\text { insurance, utilities, } \\
\text { IT, premises, } \\
\text { logistics and } \\
\text { stock/products. }\end{array}$ & $\begin{array}{l}\text { http://www.c } \\
\text { limate- } \\
\text { em.org.uk/i } \\
\text { mages/uploa } \\
\text { ds/Weatheri } \\
\text { ng_the_Stor } \\
\text { m_updated_- } \\
\text { 2012.pdf }\end{array}$ \\
\hline $\begin{array}{l}\text { Environment } \\
\text { Agency: "Would } \\
\text { your business } \\
\text { stay afloat? A } \\
\text { guide to } \\
\text { preparing your } \\
\text { business for } \\
\text { flooding" }\end{array}$ & $\begin{array}{l}\text { Support with } \\
\text { creating a flood } \\
\text { plan for your } \\
\text { business }\end{array}$ & $\begin{array}{l}\text { https://www. } \\
\text { gov.uk/gove } \\
\text { rnment/uplo } \\
\text { ads/system/u } \\
\text { ploads/attach } \\
\text { ment_data/fi } \\
\text { le/410606/LI } \\
\text { T_5284.pdf }\end{array}$ \\
\hline $\begin{array}{l}\text { Business } \\
\text { Continuity } \\
\text { Institute: } \\
\text { "Fighting back } \\
\text { the tide: } \\
\text { protecting your } \\
\text { business against } \\
\text { flooding" }\end{array}$ & $\begin{array}{l}\text { A list of questions } \\
\text { to ask yourself } \\
\text { regarding: } \\
\text { customers, } \\
\text { suppliers, staff, IT, } \\
\text { telecoms, premises } \\
\text { and reputation. }\end{array}$ & $\begin{array}{l}\text { http://www. } \\
\text { bcipartnershi } \\
\text { p.com/Exerc } \\
\text { iseWatermar } \\
\text { kBCISMEgu } \\
\text { idetoBCM_F } \\
\text { INAL.pdf }\end{array}$ \\
\hline
\end{tabular}

\section{Methods: Processes of co-production}

Our processes of co-production have involved small businesses, and organisations that support such businesses with their resilience planning. In these processes, we worked with two groups of end-users throughout the research and development. The first group, which we termed a Business Research Partnership Group (BRPG), comprised small businesses from Tewkesbury, a small town on the lower part of the River Severn, UK. This group comprised ten people and included representation from the retail, transport, catering, leisure, health and manufacturing sectors. 
Tewkesbury has regular experience of routine floods and also experienced severe river and surface water flooding during the UK 2007 Summer floods. Within the established core of the town, inhabitants have a strong 'watery' sense of place. Prior to the establishment of this group, we had conducted research interviews with several of these businesses on the topic of flood resilience.

The second group was a stakeholder group variant of the Stakeholder Competency Group (SCG) model proposed by Landström et al. [10]. An SCG involves the development of collective expertise on an issue through collective research in which the stakeholder is a research partner. Our Stakeholder Competency Group (SCG) comprised fifteen people from national and regional organisations that work with small businesses to increase their resilience in relation to flood risk and for wider risk planning. These included: representatives from Business in the Community (an organisation that promotes the role of businesses in community working); the Federation of Small Businesses (a national and regional business support group); the National Flood Forum (a self-help charity run by those who have experienced flooding); local resilience fora (inter-professional teams for local resilience planning); along with local authority flood planners and business resilience advisers from rural community councils.

This co-production process lasted 18 months and involved several different activities. The SCG and BRPG each met twice with the researchers and there was a combined meeting of both groups and the researchers near the end of the research process. Data on coproduction processes were captured through: independent and participant observation, audio/visual recording, transcription of discussions, and the participatory production of graphic outputs. Both groups communicated virtually in follow-on discussions. The academic team also worked with individual BRPG members to develop resources for the e-learning tool. End-of-process interviews to capture perceptions of the research co-production processes will take place in March/April 2016.

\section{Approach to co-production processes}

To start off the research process, we engaged both sets of partners in reflecting on what co-production might look like in the context of this project. We also conducted research to develop the e-learning tool - its concept, structure, design, content, media and messages. This process captured businesses' and wider stakeholders' opinions about how the learning tool should be framed and its key design premises.

The initial meetings with the two groups formed an important developmental stage in the research process by providing information that informed the tool's specification. Meeting 1 involved an exploratory mindmapping exercise that covered: how the tool could be used; how it could map onto to the flood cycle (flood respond to the flood -recover from the flood -adapt ahead of the next flood); and how it could engage small businesses. Figure 1 shows a mind map generated from SCG Meeting 1; Figure 2 shows output from a group flow-charting activity on insurance decision-making.

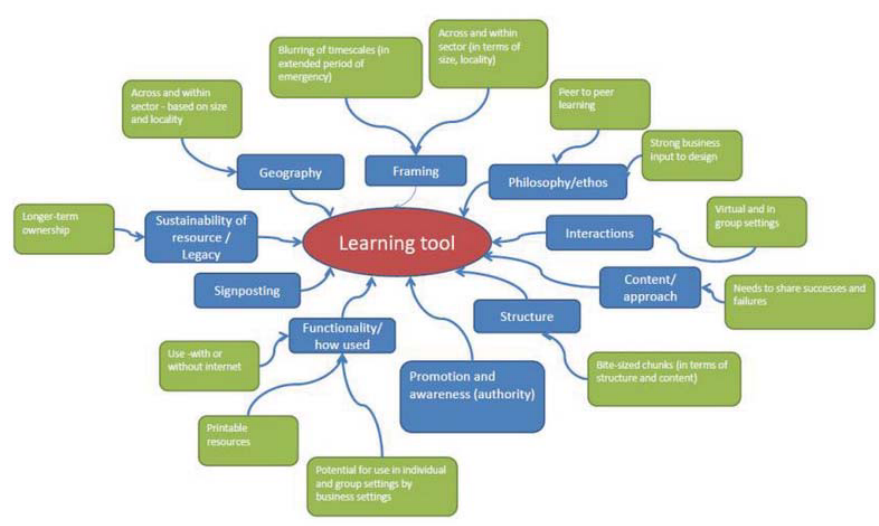

Figure 1. A mind map generated from SCG Meeting 1

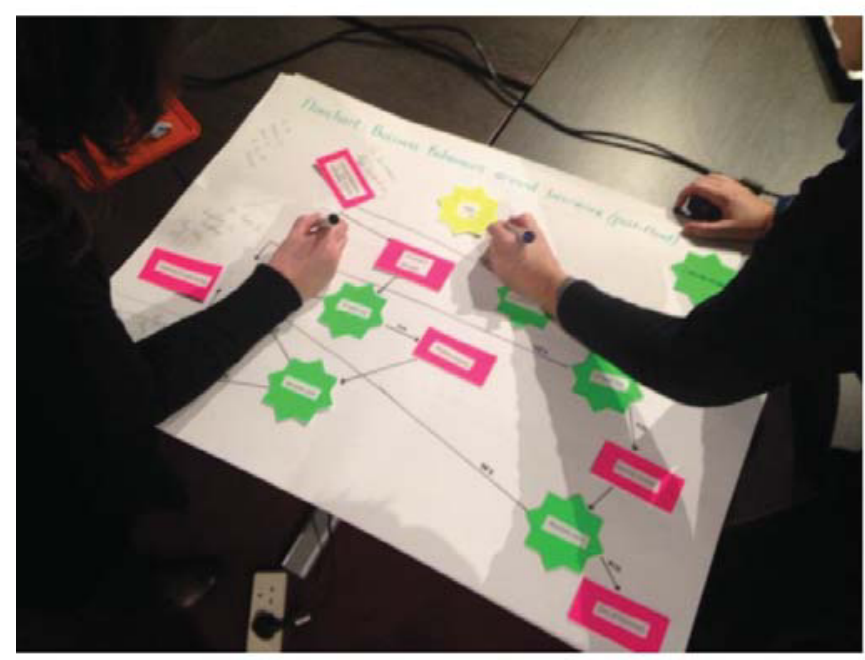

Figure 2. A flow-charting activity on insurance decisionmaking.

Meeting 2 involved an exploration of different thematic 'ways in' that could be used to structure the learning resources meaningfully, and a critical examination of possible media/messages that would engage small businesses on the topic of adaptation. The value of the following learning resource options was discussed: written narratives, digital storytelling, podcasts, flow charting based on the project's AgentBased Modelling ${ }^{3}$, virtual poster boards and social media.

\footnotetext{
${ }^{3}$ The interdisciplinary project had four parts, of which one involved the Agent Based Modelling of business behaviours.
} 
Subsequently the process involved the co-production of learning resources with local business people, and drew on their experiential knowledge of how to adapt to flooding. Meeting 3 (a combined meeting of the BRPG, the SCG and the researchers) had three aims: to review progress with the e-learning tool and gain feedback for its final development stages; to celebrate local contributions to the tool; and to collect research data on co-production processes by reflecting on the experiences of involvement in the tool development.

\section{Draft findings: research processes and outcomes}

Both groups provided rich exchanges about how small businesses learn and what the e-learning tool should look like if businesses are to engage. Emphasis was on, for example, learning styles 'bite-sized chunks', importance of attitudinal change, and business to business communication (for example, see Box 1).

Box 1. Comments from the SCG in the early development of the e-learning tool

'Keep it simple - whatever the tool ends up looking like, it's got to be immediate, quick and good language, and there are other sources to get information from. And we are all like this on the web: if you hit a page and you don't like it, you don't go back to it.'

'And something they can dip in and out of easily - when you are running a business, you are juggling several things in the air so something that they can take something very quickly away from it.'

'Needs to be quickly updated as well - a lot of it is a moving feast - we live in a 24 cycle now - there is News 24 - no good having a dead website - this has to be live, open and updated.'

'Fundamentally it's a change of attitude isn't it, a change of awareness, a change of engagement.'

'It's really how we get that learning to happen - it's messages and learning.'

'We also said 'learning from other businesses, as well as advice from public sector bodies; so we're not dissing the public sector bodies.'

Our experience confirms that effective co-production requires long-term relationships and trust-building with all stakeholders through the co-production processes. This included being responsive to formal and informal opportunities for dialogue, and requests to share knowledge in whatever form. We found that there is also a need to make space early in co-production processes to work through any barriers to co-production that might arise. For example, we saw the BRPG move from scepticism to enthusiasm as the co-production progressed. Initially, participants focused their contributions to the group on the questions of who was to blame for the floods they had experienced and what government agencies should be doing to prevent renewed flooding. In this way, they revealed their need to work through the emotional side of their collective flood experiences. As a result, in the first meeting some found it hard to focus on the issue of longer-term adaptation (cf. the common tendency to focus on responses to a flood rather than long-term preparations ahead of the next flood). However, we knew that we were engaged in a genuine partnership when there was a shift from the use of 'your tool' to 'our tool' (Box 2).

Box 2. Comments from the BRPG in the early and later stages of development of the e-learning tool

Meeting 1 :

'We all get a little bit out of it but the fact that those of us have been flooded had a chance to have a whinge and release our stress - which helps a certain amount - but we need, not only we but others need, to gain something for all the effort and work that is going into this.'

'I hope that what we have gone through actually produces a working document and a working programme to help others otherwise its worthless.'

Meeting 3 :

'I was absolutely made over with our new Sesame Tool today. Yes it needs tidying up and tweaking, but I believe it could be the basis of a real Countrywide Flood management tool kit. Great stuff, we must not rest on our laurels but it is a great start.'

The business people also argued strongly that they preferred to learn from other businesses rather than from government agencies. Furthermore, they privileged narrative and visual approaches to communication particularly the notion of self-authored digital narratives - and argued that learning resources were most powerful when they were strongly linked to the local. The language used when communicating about adaptation was considered particularly important; for example, the use of terms such as 'resilience' and 'emotion' was objected to by some participants.

\section{Co-production of learning resources}

A strong element of co-production occurred in the development of the narrative resources that predominate in the tool. Some of these consisted of short reflections recorded in the author's voice and accompanied by 
images selected by the author; these can be termed forms of 'digital story'. Six digital stories were co-produced with members of the BRPG, in the form of life stories, reflective accounts or testimonies. Within these, business people shared their learning about how to run a business in a flood risk area, and on different aspects of their adaptive strategies. Titles included:

- Knowing the situation and getting on with it

- Sorting out the insurance

- Being ready to keep the water out

- Still open for business

- Resilience after the flood

- Learning to work differently

Storytelling processes were found to encourage critical reflection on business adaptation, decision making and experiential learning and to encourage participants to share these with other small businesses. All three films in the e-learning tool had co-selected topics and co-produced scripts and settings, and involved academic specialists and local business people sharing their knowledges about local flood risk or property-level resilience. This approach represented a deliberate movement away from traditional science communication podcasts in which only the academic has a voice.

\section{Implications for the e-learning tool}

The aspiration for the learning tool was that it should be distinctive by being research-informed, narrative in orientation and draw on different evidence bases. The etool is therefore planned as a living resource that could be used to support a community of learning practice among small businesses to increase resilience in the face of increased flood risk. The resultant structure of the elearning tool informed by these interactions is division between 'I have just been flooded' and 'Become more flood resilient'. Seven thematic 'hooks' or 'ways in' to the tool were discussed, framed and prioritised with both groups (Figure 3 provides a graphic example from BRPG Meeting 2).

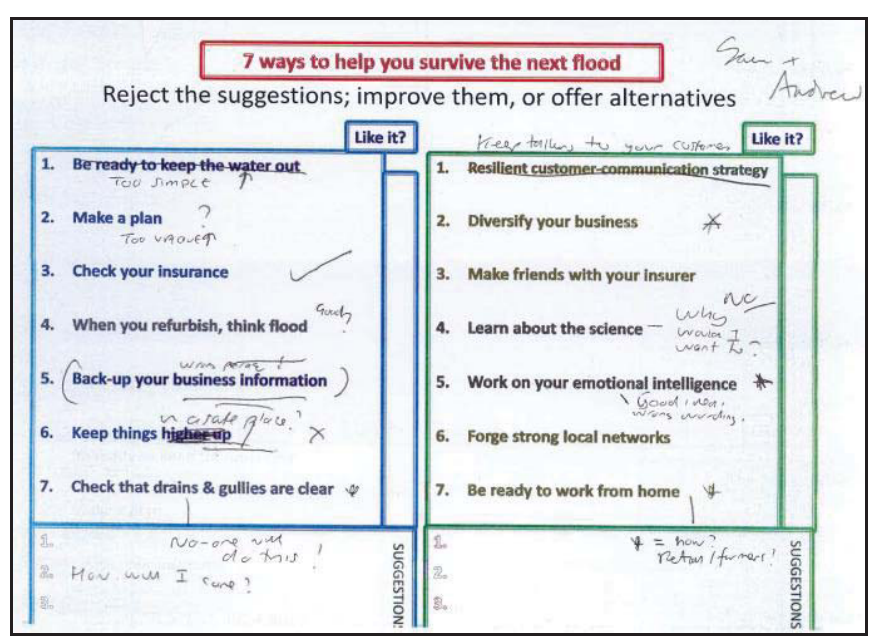

Figure 3. Example business contribution to a prioritising and wording activity

The resultant structure of the learning tool's resources, after feedback from the SCG and BGRG, was:

- Talk to customers and suppliers

- Manage the financial impacts

- Work out why your building floods

- Reduce the potential damage

- Build your emotional strength for resilience

- Build your local community networks

- Be ready to work differently

\section{Conclusions}

The co-production approach reflects current attitudes towards research ethics and the need to engage stakeholders within research so that their, equally valid, forms of knowledge are also recognised. It reflects awareness that it is important to make space for the exploration of parallels, controversies and frictions between different forms of competency and knowledge (whether scientific, local, tacit or embedded). We found that this approach strengthens research outputs and helps ensure longitudinal impact.

The use of narrative processes worked well within the co-productive process and in the production of collaborative resources. The next stage is to research perceptions of the e-tool outside the groups with which it was co-produced to secure their feedback.

\subsection{Future work and benefits to users}

The prototype e-learning tool is currently nearing completion and will be made available online in April 2016. We are planning to start a trial of the tool with Tewkesbury and Gloucestershire business communities in Spring 2016, in collaboration with the local 
government organisation for Tewkesbury. Accompanying research will explore the effectiveness of the narrative approaches taken in the tool. Key objectives now include ensuring our partnership processes are sustained beyond the project lifespan through joint working with other business resilience initiatives and business groups.

\section{Acknowledgements}

We would like to thank all the participants for their contributions to the research. We gratefully acknowledge the funding provided by the UK's Engineering and Physical Science Research Council under grant EP/K012770/1.

\section{References}

1. UK Cabinet Office (2008). The Pitt Review: Lessons learned from the 2007 floods

(http://www.cabinetoffice.gov.uk/thepittreview.aspx)

2. Twigger Ross, C., Orr, P., Brooks, K., Sadauskis, R., Deeming, H., Fielding, J., Harries, T., Johnston, R., Kashefi, E., McCarthy, S., Rees, Y. and Tapsell, S. (2015). Flood Resilience Community Pathfinder Evaluation Final Report FD1664. Report of research carried out by Collingwood Environmental Planning on behalf of the Department for Environment, Farming and Rural Affairs.

3. Leach, K. (2015) Impact of flooding and flood risk on community economic resilience in the upper Calder Valley, UK. Report commissioned by Calderdale Council and DEFRA.

4. Whatmore S. (2009). Mapping knowledge controversies: science democracy and the redistribution of expertise Progress in Human Geography 33 587-59

5. Lane S. N., Odoni N., Landström C., Whatmore' S. J., Ward, and Bradley S. 2011 Doing flood risk science differently: an experiment in radical scientific method Transactions of the Institute of British Geographers 36 15-36.

6. Donaldson A., Lane S., Ward N., and Whatmore S. (2013). Overflowing with issues: following the political trajectories of flooding Environment and Planning C: Government and Policy 31 603-618.

7. Antonacopolou, E. P. (2008). Actionable Knowledge in R Clegg and J Bailey eds. International Encyclopaedia of Organization Studies London Sage.

8. Haughton G., Bankoff G. and Coulthard T. J. (2015). In search of 'lost' knowledge and outsourced expertise in flood risk management Transactions of the Institute of British Geographers 40 375-386.
9. Twigger-Ross, C., Kashefi, E., Weldon, S., Brooks, K., Deeming, H., Forrest, S., Fielding J., Gomersall, A., Harries, T., McCarthy, S., Orr, P., Parker, D. and Tapsell, S (2014). Flood Resilience Evaluation: Rapid Evidence Review. Report of research carried out by Collingwood Environmental Planning on behalf of the Department for Environment, Farming and Rural Affairs.

10. Landström C .,Whatmore S. J., Lane S. N., Odoni, N. A., Ward N. and Bradley, S. (2011). Co-producing flood risk knowledge: redistributing expertise in critical 'participatory modelling' Environment and Planning A 43 1617-1633. 